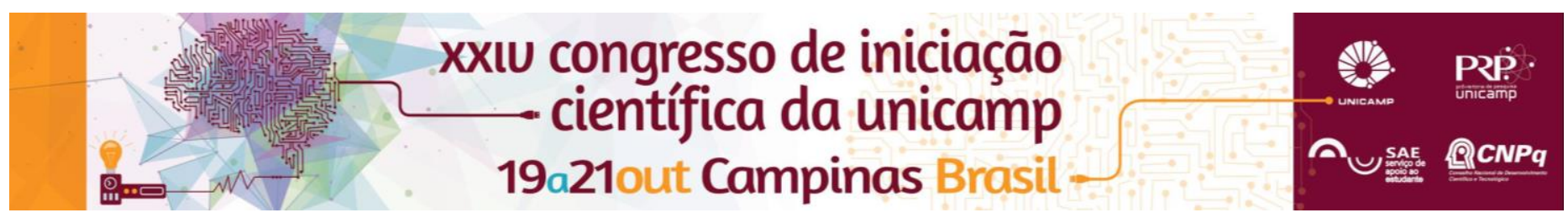

\title{
Interpretação de Dados Magnetométricos da Estrutura de Cerro do Jarau, RS.
}

\author{
André L P Tôrres*, Emilson P Leite, Julio C Ferreira.
}

\section{Resumo}

O tratamento e interpretação de dados magnetométricos é sempre uma tarefa delicada de se fazer, podendo vir a prejudicar toda uma pesquisa caso não sejam feitos com o rigor necessário. Para a Estrutura de Cerro do Jarau além dos produtos convencionais de mapas geofísicos 2D, o presente trabalho trata também da modelagem inversa 3D de subsuperfície, com vínculos de susceptibilidade das rochas presentes em superficie e modelos anteriores de subsuperfície feitos a partir de dados gravimétricos. Em nossa pesquisa, a modelagem inversa 3D de subsuperfície aliada ao conhecimento de geologia regional e local, se revela uma potente ferramenta no auxílio a interpretação de feições de superfície e subsuperfície.

\section{Palavras-chave:}

Geofísica, Dados Magnetométricos, Estrutura de Cerro do Jarau.

\section{Introdução}

A estrutura de Cerro do Jarau vem apresentando divergências quanto a sua origem desde o final da década de 1960. Grehs (1969) descreve a estrutura como um domo estrutural, em contrapartida, outros autores Moreira et al., 1980, Crósta et al., 2010 e Phillip et al., 2010 levantam a hipótese de a estrutura ser uma cratera de impacto. Recentemente, Sachéz et al., 2014, propõem a hipótese de a estrutura ser na verdade uma bacia, indo contrário as hipóteses elaboradas anteriormente.

O atual trabalho é fruto da coleta de dados magnéticos da estrutura de Cerro do Jarau no qual foram elaborados alguns produtos com objetivo de fornecer um novo acervo de dados que busque colaborar na interpretação das hipóteses já realizadas a respeito da estrutura, com a integração do atual conjunto de dados.

\section{Resultados e Discussão}

A atual pesquisa gerou dezessete produtos distintos, dois quais foram selecionados três deles para ilustrar os principais resultados. Os mapas foram gerados a partir do software Oasis Montaj $\AA$, da empresa canadense Geosofto. Para confecção dos mapas foram realizadas todas as correções necessárias desde a correção da variação diurna nos dados iniciais, passando pela remoção do IGRF e chegando a remoção do regional. Na figura 1 , temos o resultado de nossa inversão 3D da sub superfície, na figura 2, temos o mapa de redução ao pólo magnético e na figura 3 temos o mapa de domínios de susceptibilidade magnética.

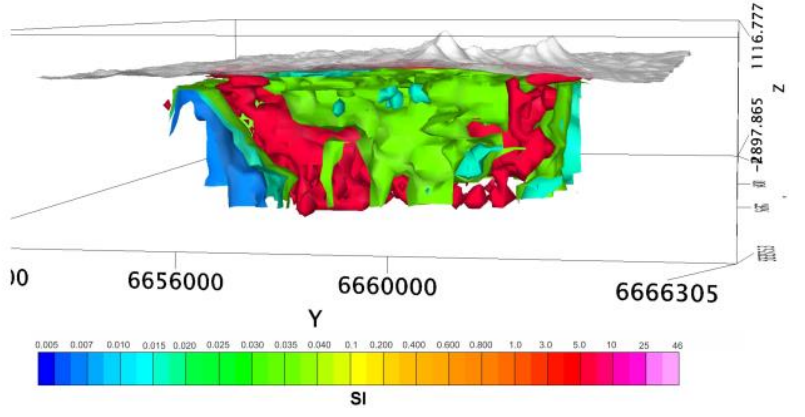

Figura 1. Em vermelho rochas com maiores susceptibilidades (Basaltos) e em verde e azul rochas de menores susceptibilidades (Arenitos).

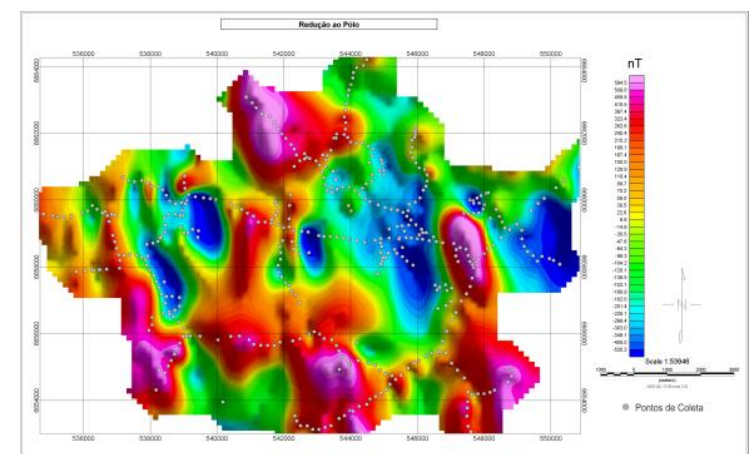

Figura 2. Mapa de redução ao pólo magnético.

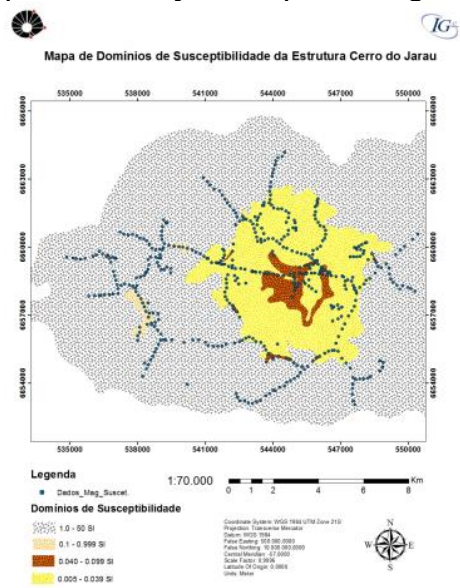

Figura 3. Mapa de domínios de susceptibilidade magnética.

\section{Conclusões}

A pesquisa mostra que ainda há muito que se discutir a respeito da estrutura de Cerro do Jarau, porém com os novos dados fornecidos na atual pesquisa, acabamos por corroborar com a hipóteses anteriores de a estrutura ser uma possível cratera de impacto, com sua borda interna preenchida por basalto, sendo este, o responsável pelos altos contrastes magnéticos e gravimétricos em formato semicircular.

\section{Agradecimentos}

Gostaria de agradecer a meu orientador, Emilson P Leite e ao Julio Ferreira pela orientação e suporte durante a pesquisa e ao órgão financiador Cnpq/Pibic pela oportunidade de poder realizar a pesquisa. 